Article

\title{
Spring 2020 Aerosol Contamination of the Atmosphere over Kyiv City
}

\author{
Chenning Zhang ${ }^{1}$, Valery Shulga ${ }^{1,2}$, Gennadi Milinevsky 1,3,4,5, , Vassyl Danylevsky ${ }^{3,6}$, Yuliya Yukhymchuk ${ }^{3}$, Vo- \\ lodymyr Kyslyi ${ }^{7}$, Ivan Syniavsky ${ }^{3}$, Mikhail Sosonkin ${ }^{3}$, Olena Turos ${ }^{8}$, Andrii Simon 5,9 , Vasyl Choliy ${ }^{5}$, Tetiana \\ Maremukha ${ }^{8}$, Arina Petrosian ${ }^{8}$, Vladyslav Pysanko ${ }^{5}$, Anna Honcharova ${ }^{10}$, Dmitry Shulga ${ }^{2}$, Natallia Miatselskaya \\ 11, Varvara Morhuleva 8
}

1 International Center of Future Science, College of Physics, Jilin University, Changchun, 130012, China; zhangcn19@mails.jlu.edu.cn (C.Z.); shulga@rian.kharkov.ua (V.S.); gmilin@univ.kiev.ua (G.M.)

2 Department of Millimeter Radio Astronomy, Institute of Radio Astronomy, National Academy of Sciences of Ukraine, Kyiv, 01601, Ukraine; dshulga@rian.kharkov.ua (D.S.)

3 Department for Atmospheric Optics and Instrumentation, Main Astronomical Observatory, Kyiv, Ukraine; syn@mao.kiev.ua (I.S.); sosonkin@mao.kiev.ua (M.S.); juliyuhim@gmail.com (Y.Y.)

4 Department of Atmosphere Physics and Geospace, National Antarctic Scientific Center, 01601 Kyiv, Ukraine;

5 Physics Faculty, Taras Shevchenko National University of Kyiv, Kyiv, Ukraine; andrew_simon@univ.kiev.ua (A.S); charlie@mail.univ.kiev.ua (V.C.); vladislav039@i.ua (V.P.);

6 Astronomical Observatory, Taras Shevchenko National University of Kyiv, Kyiv, Ukraine; vdanylevsky@knu.ua (V.D.)

7 V. Lashkaryov Institute of Semiconductor Physics of the National Academy of Sciences of Ukraine, Kyiv, Ukraine; kyslyij@gmail.com (V.K.)

8 Laboratory of Air Quality, Marzeiev Institute for Public Health, National Academy of Medical Science of Ukraine, Kyiv, Ukraine; eturos@gmail.com (E.T.); maremuha1980@gmail.com (T.M.); arinapetrosian@gmail.com (A.P.); morvara@gmail.com (V.M.)

9 National Center of Junior Academy of Sciences of Ukraine, 04119, Kyiv, Ukraine

${ }_{10}$ V.N. Karazin Kharkiv National University, Kharkiv, Ukraine; goncharova300ann@gmail.com (A.H.)

11 Institute of Physics of the National Academy of Sciences of Belarus, Minsk, Belarus; n.miatselskaya@dragon.bas-net.by (N.M.)

* Correspondence: gmilin@univ.kiev.ua (G.M.); Tel.: +38-050-3525498 (G.M.)

\begin{abstract}
Extraordinary high aerosol contamination observed in the atmosphere over Kyiv city, Ukraine, during the March - April 2020 period. The source of contamination was the large grass and forest fires in the northern part of Ukraine and the Kyiv region. The level of PM2.5 load investigated using newly established AirVisual sensors mini-network in five areas of the city. The aerosol data from the Kyiv AERONET sun-photometer site analyzed for that period. Aerosol optical depth, Angstrom exponent, and the aerosol particles properties (particles size distribution, single-scattering albedo, and complex refractive index) were analyzed using AERONET sun-photometer observations. The smoke particles observed at Kyiv site during the fires in general correspond to aerosol with optical properties of biomass burning particles. The variability of the optical properties and chemical composition indicates that the aerosol particles in the smoke plumes over Kyiv were produced by different burning material and phases of vegetation fires at different time. The case of enormous PM2.5 aerosol contamination in Kyiv city reveals the need to accept strong measures for forest fire control and prevention in Kyiv region, especially in the north-west region where radioactive contamination from Chornobyl disaster is still significant.
\end{abstract}

Keywords: aerosol; PM2.5; forest fires; AERONET; aerosol optical depth; Angstrom exponent

\section{Introduction}

Aerosol particle emissions from vegetation fires have large impacts on both climate and air quality. Biomass burning plays an important role in the climate system. Forest, grass and peat fires aerosols can be transported over long distance and influence aerosol content and properties, and air quality in populated regions. For example, large wildfires in the European part of Russian Federation which occurred in summer of 2010 influenced 
greatly on the air pollution in densely populated Moscow city and region [1,2], and the atmosphere contamination was observed overall neighboring countries [3-5]. The aerosols from the wildfire in Canada occurred during 2-7 July 2013 were observed over the Central and Eastern Europe [6].

Forest, grass and peat fires produce so-called biomass burning (BB) aerosols that are the mixture of different particles containing such substances as black carbon (soot), sulfate, nitrate, ammonium, and dust. The mixture of substances in a particle and mixture of different type of particles in the smoke plume determine the microphysical and optical properties of aerosol observed at the observational site. The particle size distribution of the BB aerosols influences the PM2.5 and PM10 concentrations, which are the air quality factor [7].

The special studies stressed on the negative impact of fine particles on the human health, (see, e.g., [8,9]). It is essential to identify accurately and quantify specific air particulate matter pollution by the BB aerosol, especially in the urban areas. In situ PM concentration measurements are common technique to estimate the air pollution in different regions of the globe [10-13], particularly using low-cost instruments for the air quality monitoring networks [14,15]. Also the remote sensing measurements are used for it [16-19], modeling [20,12] and synergy of different techniques [21]. Particularly, simulation of the air mass transport is required to estimate the wildfire aerosols influence on the air quality, which depends on the meteorological parameters [22, 23].

Kyiv city and region influenced by numerous local aerosol pollution sources and by the aerosol transport from remote sources, mostly wild and human-made forest and peat fires, grass burn. The most dangerous grass and forest fires take place in radioactive contaminated areas like Chornobyl Exclusion Zone [24]. These events release dust, biomass burn particles, soot, black carbon and radioactive Cs-137 that spread on long distances with wind transfer. The increased aerosol optical depth was observed by Kyiv AERONET/PHOTONS site in April-May every year. It is mainly caused by agricultural burn and forest/peat fires, which govern a seasonal feature of aerosol properties over the Ukrainian rural and urban-industrial areas [25]. The air transport potential influence on seasonal and local variations of aerosols content and properties at the Kyiv AERONET site has been considered in [26,25], including the 3-D back-trajectories and cluster analysis to determine the prevailing directions of air mass transport and possible aerosol origin, as well as GEOS-Chem modeling [27-29].

The purpose of this paper is to consider in details the case of intensive aerosol particles contamination of the surface atmosphere layer in the Kyiv city and the atmosphere column during the March-April 2020 period, especially on the 4 - 15 April 2020 when large areas of forest fires in north part of Ukraine including Chornobyl Exclusion Zone (ChEZ) took place. The forest fire took place also in Zhytomyr region at northwest of Kyiv city and in ChEZ till the end of April 2020.

The local AirVisual network in situ observations, established by authors in Kyiv city, and other measurement techniques used are described in Section 2. The PM concentration measured by Kyiv AirVisual network, the AERONET AOD data comparison with in situ PM2.5 concentration measurements, as well as PM2.5 concentration intercomparison with HORIBA sensors data, discussed in Section 3. Aerosol columnar microphysical and optical properties considered in Section 4 followed by discussion in Section 5 and conclusions in Section 6.

\section{Materials and Methods}

In this work, we use the set of data for the aerosol contamination event study in March-April 2020 from five sensors of the AirVisual network, the PM10 and PM2.5 APDA-371 HORIBA standardized analyzer. The ground-based measurements of the aerosol optical depth (AOD) and other aerosol parameters with the AERONET Kyiv site sun-photometer was used for analysis as the powerful tool for investigations [30,31]. The HYSPLIT back trajectories algorithm has been applied to derive the transport of aerosol 
particles. Zoom Earth maps on-line instrument [32] and the satellite remote sensing measurements by MODIS and VIIRS instruments provided fire maps with large coverage area was used as well [33].

\subsection{AirVisual data}

The five stations of the AirVisual network, used in the study, have been established by authors at the beginning of 2020. The stations are distributed in Kyiv city in the way to cover the most part of city regions. The AirVisual network stations are distributed all over Kyiv with purpose to cover as much of the city territory as possible. These AirVisual stations are Artema Street, Golosiiv, Nauky Avenue, Trostyanetska, Chornobylska Street and APDA-371 HORIBA Popudrenka station. The Golosiiv site co-located with Kyiv sun photometer AERONET/PHOTONS site. The main sensor of the network is AirVisual Pro smart air quality monitor with the advanced laser technology that provides highly accurate readings of fine particles PM2.5 with $2.5 \mu \mathrm{m}$ aerodynamic diameter down to $0.3 \mu \mathrm{m}[34]$.

The device is equipped with a SenseAir S8 mini-NDIR sensor measuring CO2 levels between 400 and 10000 ppm, specially designed optical sensor AVPM25b for aerosol concentration measurements, which allows to determine the concentration of PM1, PM2.5 and PM10 in the range from 0 to $1000 \mu \mathrm{g} \mathrm{m}-3( \pm 10 \%)$, temperature from -10 to $+40^{\circ} \mathrm{C}$, and $0-100 \%( \pm 1 \%)$ humidity. With $\mathrm{WiFi}$, the device can also transmit the measurements to an environmental pollution map [35], which displays data from AirVisual devices located in different regions of the world.

\subsection{PM-sensor HORIBA}

The Popudrenka site, which operates in accordance with European Union and United States Environmental Protection Agency (EPA) regulations, for PM10 and PM2.5 monitoring belongs to the O.M. Marzeiev Institute for Public Health of the National Academy of Medical Sciences of Ukraine (50.4593N, 30.6337E). The sampling site meets the requirements of the location representativeness when the sensor is placed out of the local sources of pollution and free from aerodynamic turbulence.

The in situ measurements of PM10 and PM2.5 mass concentrations are performed using the HORIBA APDA-371 Air Pollution Dust Analyzer, which consists of detector, pump and sampler. The PM2.5 and PM10 monitoring site provides automatic continuous measurement of mass concentrations using the industry certified principle of the beta ray attenuation method as a simple way to measure the mass concentration in $\mathrm{mg} \mathrm{m}-3$ or $\mu \mathrm{g}$ $\mathrm{m}-3$ with long-term stability. The aerosol particles deposited on the tape reduce the beta particles number achieving the detector, in direct proportion to the dust mass. Knowing the airflow rate, the dust mass is calculated. The inertial force screens particles with diameter more than $10 \mu$. When measuring PM2.5 particles, air passed through a special cyclone that filtered particles larger than 2.5 microns in size. The measurement accuracy of the method is $\pm 5 \%$.

\subsection{AERONET sun photometer data}

The ground-based network of the automatic autonomous sun-photometers AERONET (AErosol RObotic NETwork) [30,31] consists of several hundreds of observational sites located all over the globe and allows obtaining long-term series of aerosol parameters averaged in the atmosphere column at each observational site. The CIMEL CE-318 sun-photometers of various models are the principal instruments of the network. The measurements are performed in the spectral bands 440, 500, 675, 840 and $1020 \mathrm{~nm}$. The AERONET direct sun and inversion algorithms and software are used for the determination of spectral AOD and aerosol particles columnar properties from sun-photometer measurements [36-38].

The AERONET data are useful to study the local aerosol behavior and seasonal dynamics. For the purposes of the paper, we use the data of Kyiv AERONET site, which 
continuously operates since 2008 at south-west part of Kyiv city [25,39]. The Kyiv AERONET site is located on the roof of the building where the Golosiiv Air Visual sensor installed. The site operates in Golosiiv forest (50.3636N, 30.4967E), in $10 \mathrm{~km}$ southward from the city center. For aerosol parameters analysis in this paper, we use the aerosol Version 3 direct sun algorithm (DSA) level 1.5 parameters from the AERONET database: daily weighted averages of AOD at $500 \mathrm{~nm}$, and the Angstrom exponent values computed using the 440-870 nm spectral channels. In addition, the particles columnar size distribution (SD), single-scattering albedo (SSA), and complex refractive index (RI) are analyzed in the paper.

\subsection{Satellite data on fire locations}

Moderate Resolution Imaging Spectroradiometer (MODIS) is an instrument aboard the Terra (known as EOS AM-1) and Aqua (known as EOS PM-1) satellites. Terra and Aqua MODIS instruments are viewing the entire Earth's surface every 1 to 2 days, acquiring data in 36 spectral bands, or groups of wavelengths. The infrared channels provide observations of thermal anomalies/active fire. The observations are available in near real-time and for almost global coverage. The fire detection by MODIS based on absolute detection of a fire when the fire strength is enough to detect, and on detection relative to its background taking into account the variability of surface temperature and reflection of sunlight.

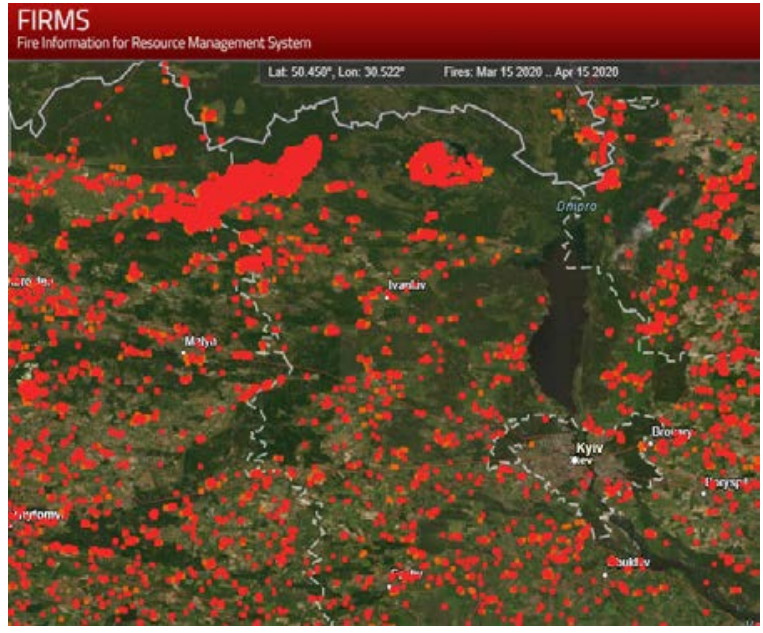

(a)

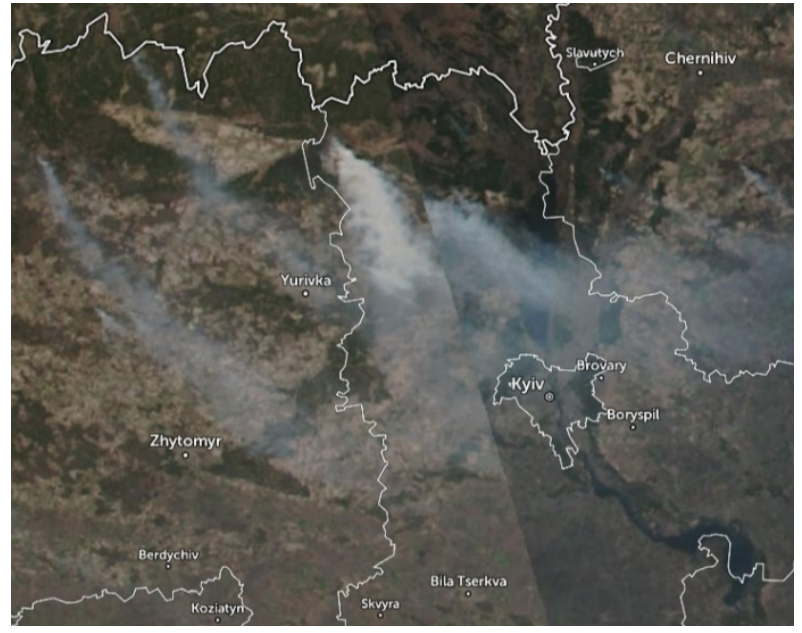

(b)

Figure 1. (a) MODIS/VIIRS fire map data March 15 - April 15, 2020, prevailed wind direction NNW, wind speed up to $27 \mathrm{~km} \mathrm{~h}-1$. Two big forest fire areas were persistent at north of Chernobyl region. (b) Satellite image April 8, 2020 with large forest fire in the northwest of Kyiv region. Plots have been created by open access data from $[32,33]$.

The Visible Infrared Imaging Radiometer Suite (VIIRS) satellite instrument collects global observations in the visible and infrared wavelengths across land, ocean, and atmosphere. It has 22 channels ranging from $0.41 \mu \mathrm{m}$ to $12.01 \mu \mathrm{m}$. VIIRS is one of five instruments onboard the Suomi National Polar-orbiting Partnership (SNPP) satellite platform. Besides measuring aerosol properties, ocean and land surface temperature, ice movement and temperature, VIIRS data product can be used for fires observations VIIRS $375 \mathrm{~m}$ resolution thermal anomalies/active fire data product and near real-time MODIS thermal anomalies and fire locations provides images of the area [33], which produced strong aerosol contamination of the atmosphere over Kyiv city (Figure 1). Satellite image for date of outburst of pollution is shown in Figure $1 \mathrm{~b}$ for April 8, 2020 with large forest fire in the north of Kyiv region [32].

\subsection{Back trajectories simulation technique}


To analyze the impact of weather conditions on the aerosols loading and transport in the atmosphere during wildfires in March - April 2020 we also calculated trajectories of air masses using Hybrid Single Particle Lagrangian Integrated Trajectory Model (HYSPLIT). This model was developed by the National Oceanic and Atmospheric Administration's (NOAA) Air Resources Laboratory (ARL) [36,37]. HYSPLIT uses a large variety of meteorological data, which are results of observations and calculations by numerical meteorological models. The following meteorological parameters are employed for computing the trajectory: horizontal components of wind speed, temperature, pressure on the altitude of the trajectory and surface pressure. Most of the meteorological data include field of vertical motion. Due to the results of detailed analysis [38] the uncertainty of calculated trajectories is $\sim 20 \%$ in the horizontal direction for the time periods of above $24 \mathrm{~h}$ in the free troposphere, and after 120 hours the uncertainty is approximately 400 km in the horizontal and about $1300 \mathrm{~m}$ in vertical planes.

The model is freely available and can be downloaded with all necessary components. However, we used the on-line version of the HYSPLIT program via AERONET/Data Synergy Tool [30,31] to compute the back trajectories of the air mass from the Kyiv AERONET site.

\section{Results}

Increasing wildfires in the spring in Ukraine and neighboring countries is a typical situation often caused by traditional grasp burning but in 2020 these events and dry weather conditions led to extensive problems as huge uncontrolled wildfires (especially in the northern part of Ukraine), largely burned territories and strong air contamination over Kyiv and others cities (Figure 1). For example, satellite observations detected numerous places of thermal anomalies in North Ukraine during data from March 15 to April 15, 2020 shown by red areas in Figure 1a. The northeast winds brought aerosol-rich airs for large distances from fire sources, dense smoke could be observed from space (Figure 1b), and Kyiv and its suburbs were covered by a powerful smoke layer from wildfire regions from time to time during these days. PM concentration and spectral AOD were observed in Kyiv and analyzed in the paper and aerosol particles properties as well.

\subsection{AirVisual in situ measurements}

Using four AirVisual sites observations, the PM2.5 data in the atmosphere over Kyiv city have been collected and analyzed during the March - April 2020 period. In March four maxima of PM2.5 were observed. The PM2/5 concentration increased up to $80 \mu \mathrm{g} \mathrm{m-}$ 3 approximately, which is three times higher than the threshold of PM2.5 pollution according to European standards of $25 \mu \mathrm{g} \mathrm{m} \mathrm{m}^{-3}$ (Figure 2a). The largest pollution was observed at the Nauky Avenue site in the first half of March, and at Artema Street and Trostyanetska sites in the second half of March 2020 (Figure 2a). On April, a significant increase of PM2.5 aerosol contamination to $40-70 \mu \mathrm{g} \mathrm{m}^{-3}$ was registered in the first half of April with maximum detected at the Trostyanetska site. The extreme contamination with the PM2.5 maximum $220 \mu \mathrm{g} \mathrm{m}-3$ was observed on April 18 (Figure 2b). The PM2.5 contamination at Trostyanetska site is largest in average daily values. Therefore, the level of pollution by PM2.5 particles is almost 10 times higher than the EU restrictions. Note that so significant contamination with PM2.5 aerosols was not local, the increase of PM2.5 was also observed at the other four AirVisual sites.

To evaluate the data accuracy and stability of measurements by AirVisual Pro sensors, we compared the data of synchronous measurements of PM2.5 by AirVisual Artema Street site and HORIBA APDA-371 analyzer at the Popudrenka site for the period March-April 2020 (Figure 3). Synchronous daily averaged measurement data of AirVisual and Popudrenka sites are shown in Figures $2 \mathrm{a}$ and $2 \mathrm{~b}$. 


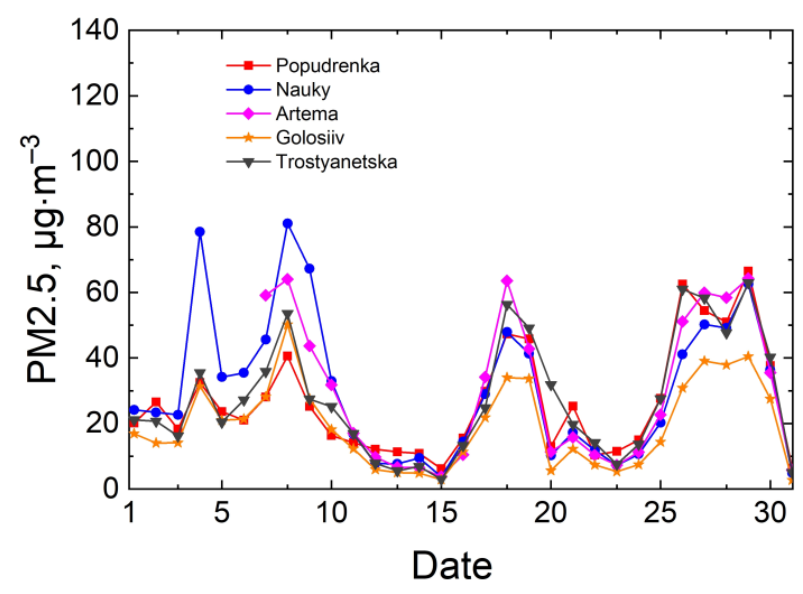

(a)

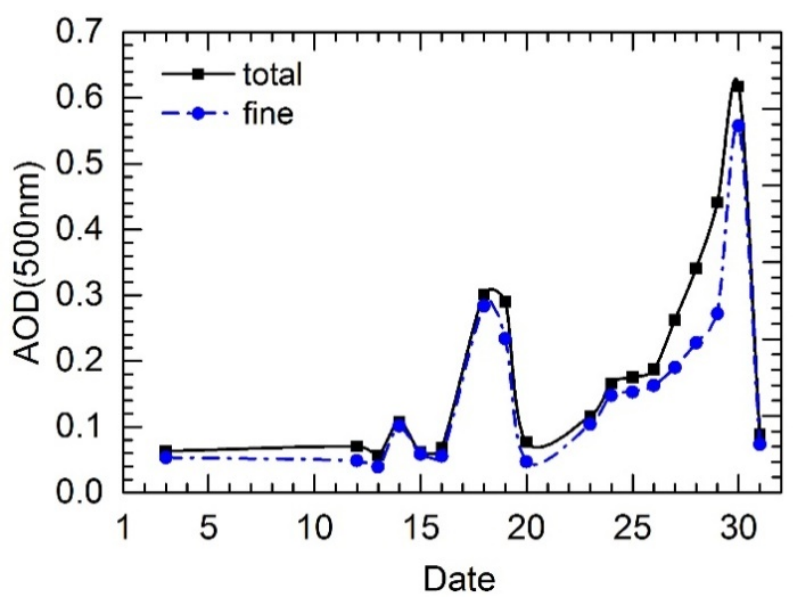

(c)

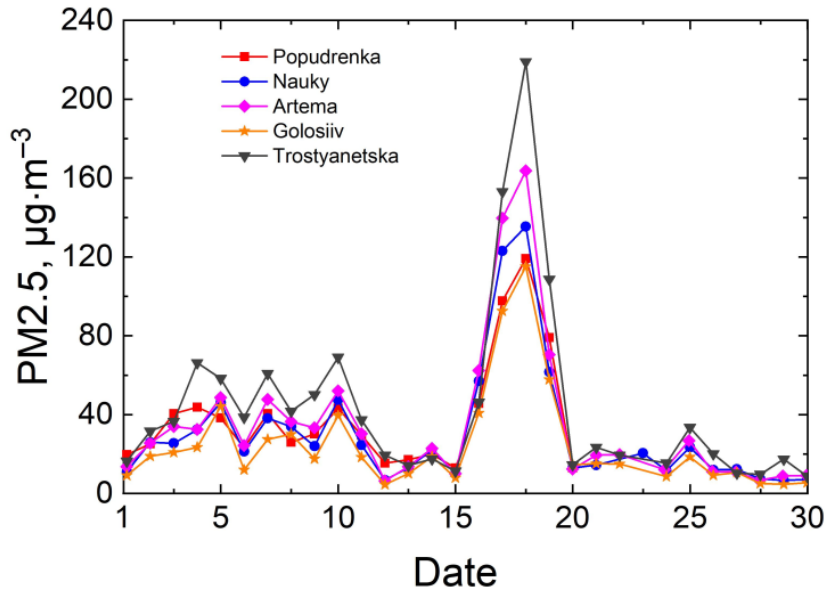

(b)

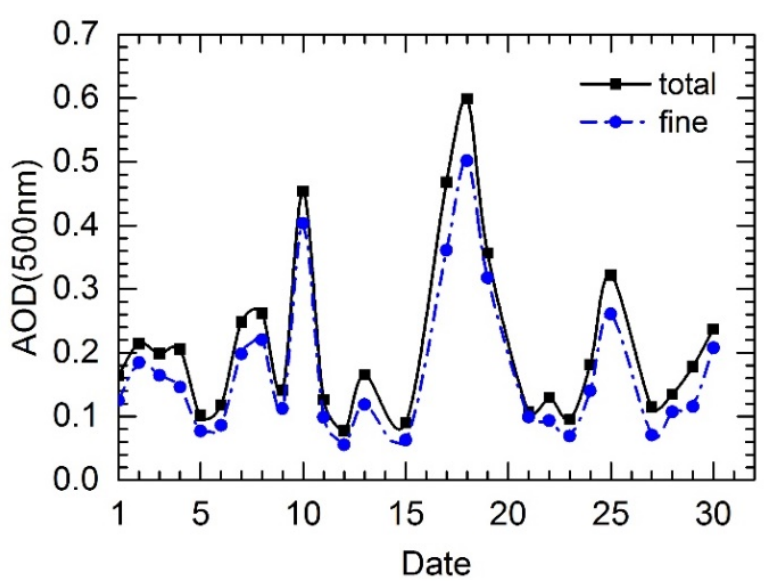

(d)

Figure 2. Air Visual network PM2.5 daily averaged measurements in Kyiv city in four sites: Nauky, Artema, Trostyanetska, Golosiiv and APDA-371 Popudrenka site in (a) March and (b) April 2020; the daily averaged AOD of all particles (total) and AOD fine particles (fine) over Kyiv from observations with AERONET Kyiv site sun-photometer at $500 \mathrm{~nm}$ wavelength during (c) March and (d) April 2020.

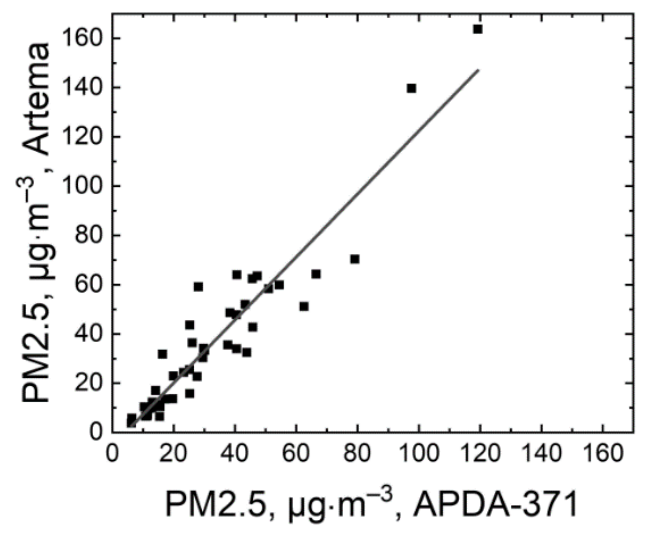

Figure 3. Comparison AirVisual PM2.5 data from Artema Street site with APDA-371 Popudrenka site simultaneous measurements March - April, 2020.

As shown in Figure 3, the values of aerosol contamination AirVisual and APDA-371 are consistent for small concentrations of PM2.5 (up to $\sim 40 \mu \mathrm{g} \mathrm{m}^{-3}$ ), but the divergence in- 
creases at values of PM2.5 more than $60 \mu \mathrm{g} \mathrm{m} \mathrm{m}^{-3}$. Linear regression with Pearson correlation coefficient $r=0.94$.

\subsection{AOD data from Kyiv AERONET site}

In this paper, we use level 1.5 of AERONET data, which is tested and corrected for the cloud impact under Version 3 (V3) of the standardized algorithm for processing observational data, adopted in the AERONET network [37]. Although sun-photometer data have been not yet corrected for possible changes in photometer calibration, experience with sun-photometer shows those significant changes in sun-photometer parameters over a period of 2 months are very unlikely. Therefore, we are confident in data reliability and to conclude these changes in the parameters of the aerosol layer are real. Analysis of the previous observations showed that typical AOD values at wavelengths $500 \mathrm{~nm}$ at Kyiv site do not exceed 0.2-0.3 [5,25,39]. During March-April 2020 significant AOD increasing were detected from sun-photometer observations of the Kyiv AERONET site (Figure 2c, 2d): in March (18 and 19 and from 27 until 30) and in April (10, from 17 until 19, and 25). The aerosol content increases mainly due to the fine mode of aerosol. In the AERONET algorithm the particles volume size distribution is determined using the bimodal lognormal model, which consist of fine and coarse modes [36,38]. Minimum of the two-modal size distribution is a boundary between fine and coarse modes that lies in the particle diameter range 1 to $2 \mu \mathrm{m}$. This means that the fine mode AOD is formed by the aerosol particles with a diameter of $\sim 2 \mu \mathrm{m}$. The fine mode AOD is determined by spectral discrimination algorithm from spectral AOD measurements [39] using bimodal lognormal model of aerosol particle size distribution.

Comparison of the AOD measured by the remote sensing with the ground-based data of the AirVisual PM2.5 concentrations shows changes of AOD(500 nm) synchronous with PM2.5 (Figure 2) despite the gaps in the observations of the AOD due to clouds. Both data series show a significant increase of air pollution over Kyiv on March 17-19 and 25-30, and during April 16-19. The cloudiness explains the data gaps from 3 to 12 March and during some other days in March and April (Figure 2c, d). In general, the AOD increases at the same periods as the PM concentrations increase (Figure 2a, b) but some discrepancies occur between AOD and PM2.5 data (see Figure 2b and compare Figures 2a and 2c). Thus, PM2.5 concentration on March 17-19 was the same approximately as on March $25-30\left(\sim 40\right.$ to $\left.70 \mu \mathrm{g} \mathrm{m}^{-3}\right)$ but AOD increasing was very different, $\operatorname{AOD}(500 \mathrm{~nm})$ was not more than 0.3 during former period and more than 0.6 during latter. On the contrary, on April 10 the sun-photometer registered a significant increase in AOD relative to its normal values from 1 to 15 April, while ground-based PM concentration measurements showed a more or less stable, but relatively high level of PM2.5 concentrations. Apparently, this is possible due to the peculiarities of the movement of air masses at different altitudes, and the increase in AOD on this day could be caused by the transport of aerosol particles from distant sources above the surface layer of the atmosphere.

Aerosol particles usually concentrated in boundary layer from the surface to a height a few kilometers during such events. For example, measurements of the aerosol altitude distribution over Kyiv by lidar measurements during a similar case of air pollution from forest fires in early September 2015, revealed aerosol particles from the surface and up to 4-5 km [40]. The satellite CALIOP lidar data analysis in July-August 2010 during large-scale forest fires in the European part of Russia showed that the products of aerosol fires over Ukraine were observed from the surface to altitudes of $6 \mathrm{~km} \mathrm{[5].}$

\subsection{Back trajectories}

Back trajectories of the air mass indicate the influence of the large forest fires in the north region of Ukraine on the aerosol content and properties in the atmosphere of Kyiv 
in the spring of 2020. The back trajectories for Kyiv were computed with on-line version of HYSPLIT model [41-43] for altitude 0.1 to $5 \mathrm{~km}$ above ground level (AGL). The altitude of the lowest trajectory was about $100 \mathrm{~m}$ over the instrument locations.

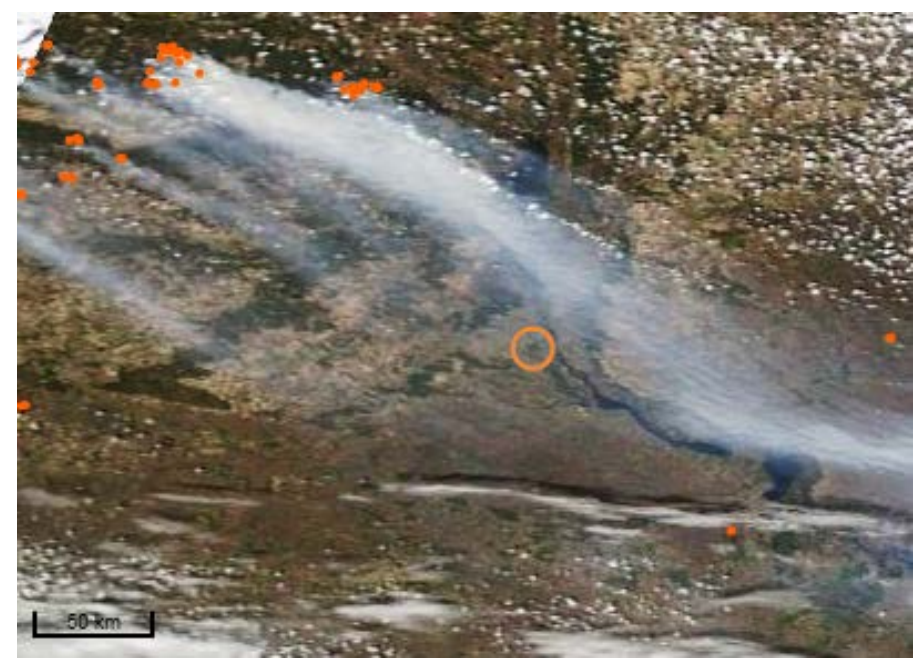

(a)

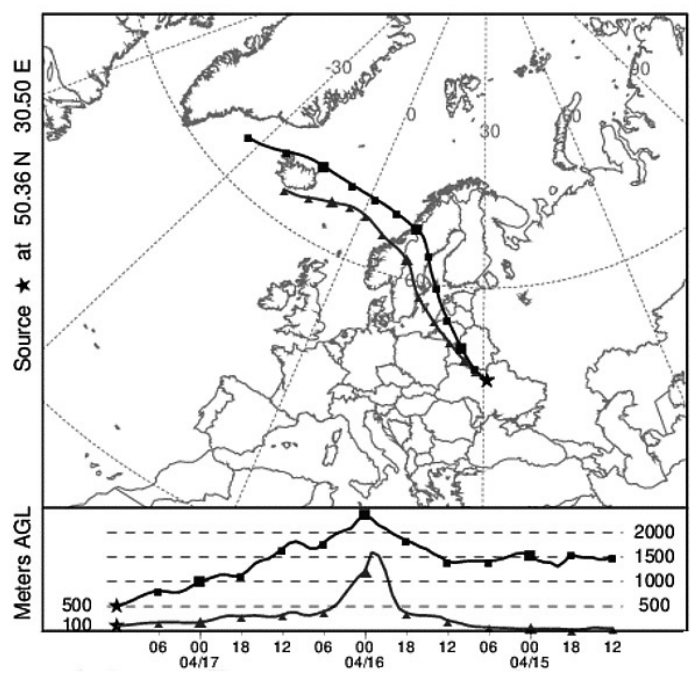

(b)

Figure 4. Smoke plumes of the forest fires in the north part of Ukraine on April 17, 2020: (a) MODIS/Terra image, (b) back trajectories on altitude 100 and 500 m AGL for Kyiv AERONET site on April 17 passed over territories with fires. Kyiv and Golosiiv observational sites location marked with a circle in the right bottom corner of (a). Plots have been created by open access data from [36].

Back trajectories on altitude $100 \mathrm{~m}$ to 1500 AGL for Kyiv AERONET site on March 26-30 passed over territories with fires during previous 3 days. Fires were the largest during March 26-28. These fires were the most probable cause of aerosol loading of the atmosphere over Kyiv on those days.

Increased pollution of the air in Kyiv on April 17-19 was caused by the large forest fires, which took place in the northern region of Ukraine, north-west from Kyiv. Smoke trails from the fire locations visible on the MODIS pictures (Figure 4a) show it. Also the back trajectories of the air mass movement for Kyiv (Figure $4 \mathrm{~b}$ ) indicate the north-west wind and the air pass over the fires. Distances from location of fire to the Golosiiv observational site ranged 90 to $240 \mathrm{~km}$ approximately as it can be estimated using the scale of the MODIS pictures. The largest fires were located at the distance about $200 \mathrm{~km}$. The air mass moved to Kyiv from the azimuth direction approximately 300@ almost without mixing the air layers in altitude range from surface to $1500 \mathrm{~m}$ AGL (Figure 4b), but air speed was different for different altitudes.

Properties of the aerosol particles depend on the time of smoke travel from fire to the observational site (see e.g., [6]). The particles undergo changes because of aging, hygroscopic growth, and mixing with other pollutants. The more time the more changes. In addition, the time travel dependence on the altitude of the air mass means that the AirVisual sensors and the sun-photometer can observe different aerosol particles at the same time. Taking into account the air mass speed dependence on altitude, the sun-photometer observe more "fresh" aerosol compare to AirVisual sensors.

\section{Discussion}

Changes of aerosol columnar properties during air pollution over Kyiv and surrounding areas were estimated using data of the AERONET Kyiv site. Variations in the main parameter of aerosol contamination $\operatorname{AOD}(500 \mathrm{~nm})$, which is proportional to the aerosol content in the atmosphere column, were discussed in Section 3.2. Here we consider other characteristics that allow estimating the size of aerosol particles and making 
assumptions about their nature: Angström Exponent (AE), dependence on AOD and particles volume size distribution averaged on the atmosphere column.

\subsection{AOD and Angstrom Exponent}

Angström Exponent (AE) is determined as $\mathrm{AE}=\frac{\ln \left(\mathrm{AOD}\left(\lambda_{1}\right) / \ln \left(\mathrm{AOD}\left(\lambda_{2}\right)\right.\right.}{\ln \left(\lambda_{2}\right) / \ln \left(\lambda_{1}\right)}$ and varies with the choice of wavelengths, $\lambda 1$ and $\lambda 2$ [46]. In general, the AE can be calculated from two or more wavelengths using a least squares fit. The AERONET algorithm defines AE in the range of 440-870 nm. The Angström Exponent contains information on the size of the particles and determines the dominant aerosol mode (coarse or fine) [38,44]. The larger $\mathrm{AE}$, the smaller particles are present in the atmosphere. Values of AE greater than 2.0 indicate fine mode particles (e.g., smoke particles and sulfates) exist, while values of $\mathrm{AE}$ near zero indicate the presence of coarse mode particles such as dust or organic aerosols. Scattering by molecules results in AE of $\sim 4$ [46].
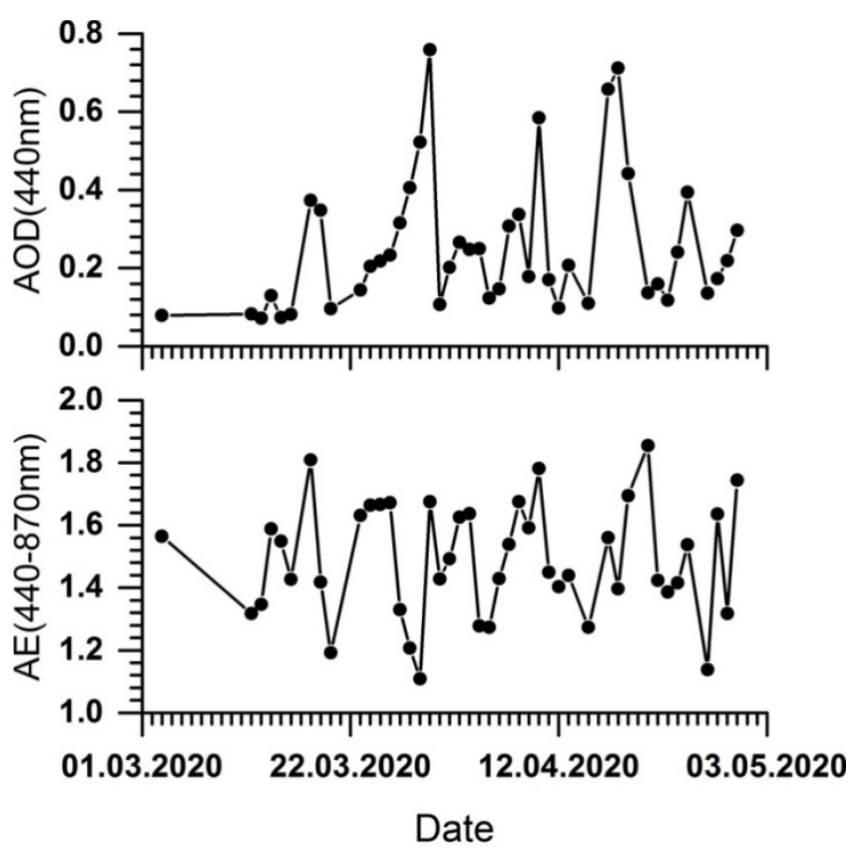

Figure 5. Daily averaged (top) AOD(440nm) and (bottom) Angstrom Exponent from the AERONET Kyiv site sun-photometer observation during March-April 2020.

More details on the change of the daily averaged $\mathrm{AOD}$ and $\mathrm{AE}$ variations during the period of significant pollution from March 15 to April 21, 2020 are presented in Figure 5. Variations of the daily $\mathrm{AE}(440-870 \mathrm{~nm})$ (Figure $5 \mathrm{~b}$ ) are in the range of 1.6-1.8, which indicates the presence of a fine aerosol mode in the atmosphere produced by forest fires and urban aerosols.

After March 26, the AE values decreased following to the AOD increase, which indicated the coarse mode aerosols incoming to the atmosphere column over Kyiv up to March 30 when $\mathrm{AOD}(440 \mathrm{~nm})$ reached peak value equal approximately 0.8 (Figure 5a). Then AE increased again to 1.6-1.7 on March 31 and changed in the range approximately 1.7 to 1.2 with the typical $\mathrm{AOD}$ at Kyiv site $(\mathrm{AOD}(440 \mathrm{~nm})=0.1-0.3)$ up to April 10. The aerosol content and properties variation during those days, as well as during end of April and start of May, is not interesting for analysis because firstly low aerosol content determined from low number of observations, and secondly the $\mathrm{AE}$ short-time variations suggest that AOD variations were provoked by aerosol of the various origins. On April 10 the AOD increased dramatically and AE values indicate the fine mode aerosol dominant in the atmosphere column. It is obvious, that the smoke plume passed over the Kyiv site on that day. Significant pollution of the atmosphere in Kyiv with biomass burning aerosol occurred during April 16-20 (Figures $2 b$ and 5a). The AE increasing from 1.4 to 
1.85 indicates that the fine mode particles dominated in the atmosphere column on those days.

Spectral dependence of AOD characterized with AE is determined by aerosol particles size distribution and spectral dependence of the particles refractive index (RI) [46]. The particles size distribution is determined from the AERONET sun-photometer observations together with single-scattering albedo and RI using AERONET algorithms $[37,39]$. These aerosol particle parameters depend on the particles origin and evolution in the atmospheric circumstance.

March 29

April 17
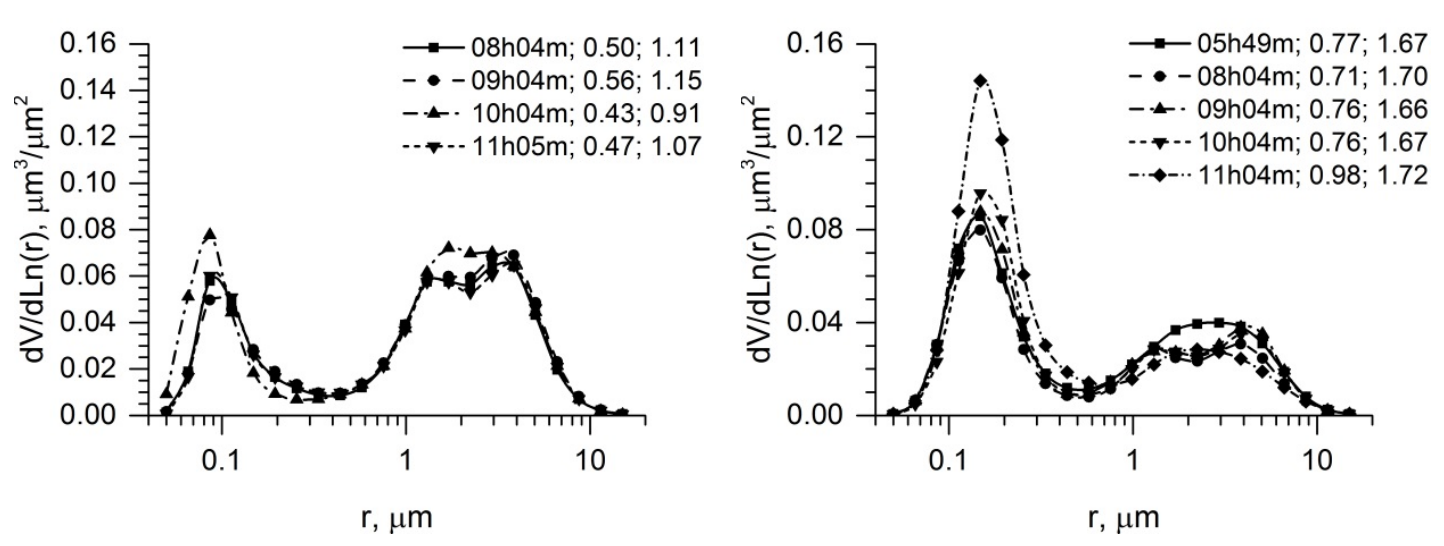

(a)

(b)

Figure 6. The aerosol particles columnar volume size distributions in the atmosphere over Kyiv from sun-photometer observations (a) March 29, 2020; (b) April 17, 2020. The legend show the time UTC of observation, $\mathrm{AOD}(440 \mathrm{~nm})$ and $\mathrm{AE}(440-870 \mathrm{~nm})$.

Observations with sun-photometer at Kyiv site during the events of the forest fires in March and April of 2020 qualified to determine the aerosol size distribution were sparse because clouds. There were 20 successful blue-sky sun-photometer observations with appropriate quality data to determine the aerosol size distribution in the period March 28 - April 19, 2020. The data showed that particles size distribution was very variable (Figure 6). During $29 \mathrm{March}$, the coarse mode particles predominated over the fine mode only. In most of the other cases, the fine mode was dominant.

\subsection{Single-scattering albedo and refractive index}

The single-scattering albedo (SSA) is an important property of the aerosols. SSA is defined as ratio of the AOD caused by the scattering feature to the AOD caused by total extinction (scattering and absorption) property of the particle and is determined with the AERONET aerosol retrieval algorithm from sun-photometer observations of the sky radiance along almucantar of the Sun at 440, 675, 870 and $1020 \mathrm{~nm}[37,39]$. SSA depends on the complex refractive index (RI) of the aerosol particle, and both parameters are determined by the aerosol retrieval algorithm and analyzed together. The complex RI consists of the real and imaginary parts, and determines microphysical and chemical properties of aerosol particles. Particularly the imagery RI determines the absorption properties of aerosol particles. Knowing the values of these two parameters, nature and basic chemical composition can be assumed. 

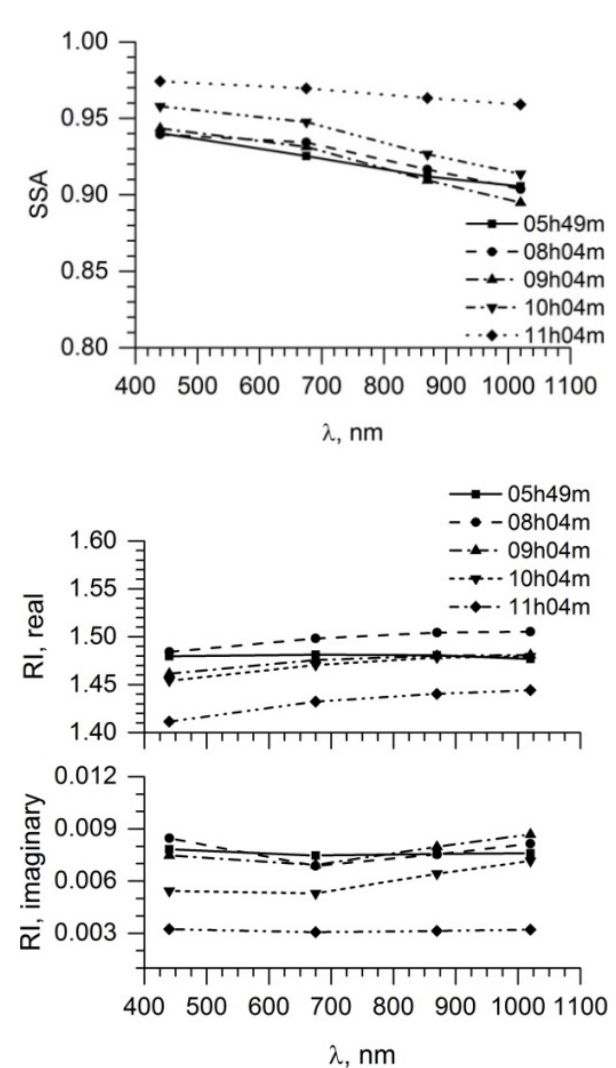

(a)
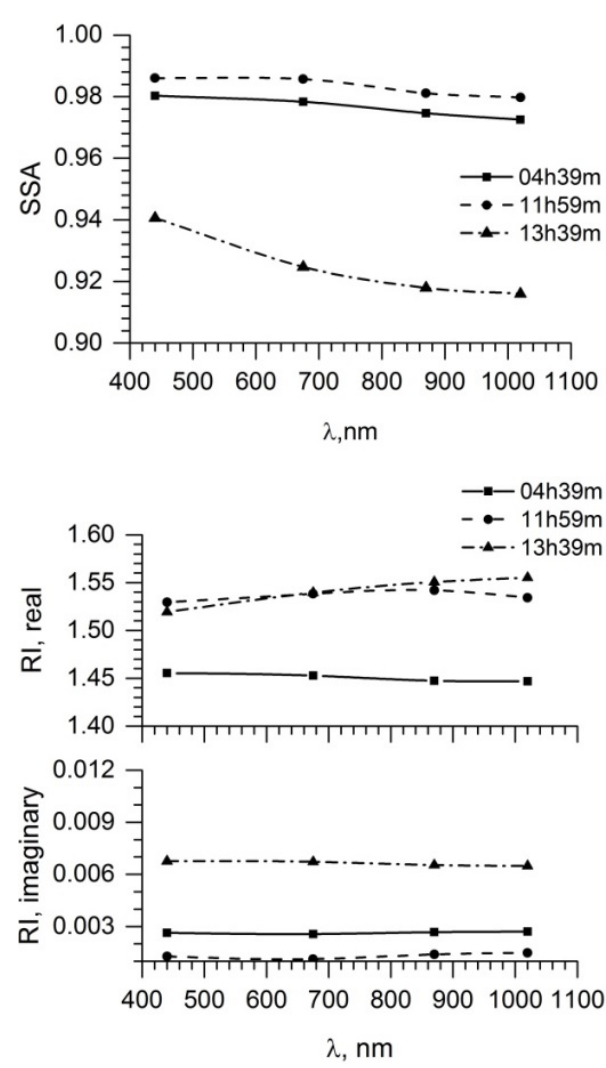

(b)

Figure 7. Spectral SSA and complex RI in the atmosphere over Kyiv from sun-photometer observations at (a) March 29, 2020; (b) April 17, 2020. The legends show the observation UTC which is the same as on the Figure 6.

The columnar SSA and RI determined for the aerosols observed at Kyiv AERONET site during events of significant pollution of the atmosphere in March and April 2020 were very changeable both in value and in spectral dependence (Figure 7). The SSA and RI variation is very significant both from day to day and during each day. The large values of SSA were retrieved on March 30, April 17-18, when SSA(440nm) was approximately 0.97 to 1.0 and $S S A(1020 \mathrm{~nm})$ from 0.90 to more than 0.99 . The lowest values of SSA were retrieved on March 28 - 29 with SSA(440nm) and SSA(1020) not more than 0.88 . However, generally the SSA values were quite high during those events of the aerosol loading in the atmosphere over Kyiv. In addition, the prominent feature was variation of the spectral dependence of the SSA for those events. Although SSA $(440 \mathrm{~nm})$ was generally larger than SSA(1020nm), except for March 29, the slope of the wavelength dependence was various during a day.

\subsection{Comparison AOD and PM2.5}

The results of measurements of PM2.5 concentrations by AirVisual stations were compared with PM2.5 concentrations measured by the EU-certified APDA-371 HORIBA sensor, as well as with data on the optical thickness and characteristics of aerosols in the atmospheric column above Kyiv from observations with the sun-photometer of the AERONET site (Figure 8). The comparison is the way to estimate the reliability and accuracy of the PM2.5 concentration measurements. The data of AirVisual stations are in good agreement with the PM2.5 values variations at Popudrenka station (Figure 3a, b). The measurements also show a spatial difference between AirVisual stations. If in March, the highest PM2.5 values were observed at Nauky Avenue and Artema Street stations, in 
April the highest (extreme) pollution levels were observed at Trostyanetska station. The lowest values of PM2.5, as expected, were observed at Golosiiv station, which is located in the forest-park zone on the outskirts of Kyiv. However, the time variations of PM2.5 concentration at this station also follow the variations of PM2.5 at other stations.

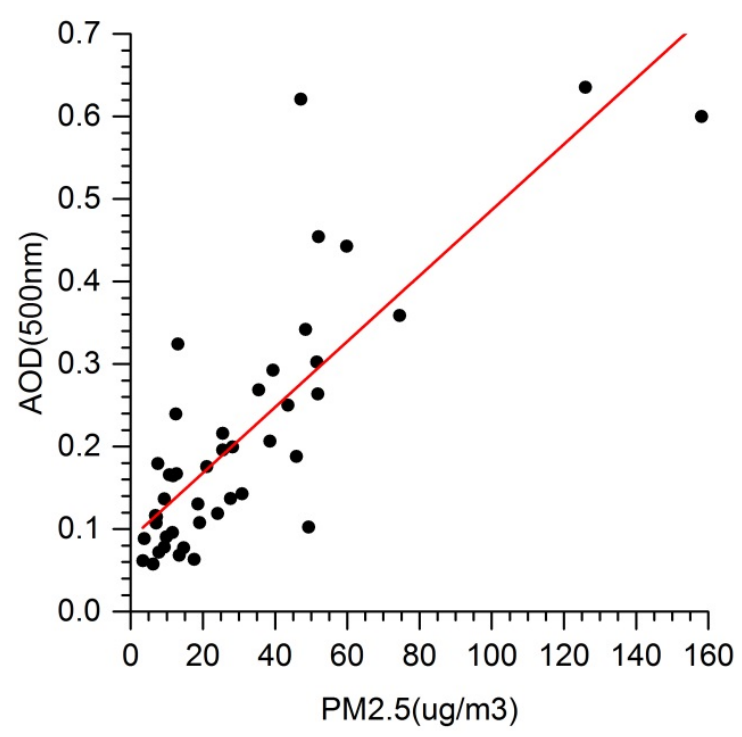

Figure 8. Comparison of the daily averaged PM2.5 concentration with daily AOD(500nm) data from AERONET Kyiv site for March - April, 2020.

To compare PM2.5 concentration and AOD data, the daily averaged PM2.5 data obtained at four sites (Artema Street, Popudrenka, Nauky Avenue and Golosiiv) were used on the days when AOD were measured with the sun-photometer at Kyiv AERONET site during March and April 2020. The daily PM2.5 data were averaged over four AirVisual sites and compared with corresponding daily averaged AOD(500nm). The equation of linear regression

$$
\operatorname{AOD}(500 \mathrm{~nm})=a+b \cdot \mathrm{PM} 2.5(\mathrm{PM} 10)
$$

was used to quantify the AOD versus PM2.5 and PM10 relations. Obtained parameters of regression: Pearson's correlation coefficient $r=0.81$, standard deviation (SD) of values $0.088 ; a=0.088 \pm 0.019 ; b=0.004 \pm 0.0004$. Formally the $r$ value indicates the close relationship between AOD and PM2.5 parameters of the atmosphere pollution but it is obviously caused mainly by high contamination level in the near-ground air and atmosphere column on two days in April 17 and 18. On the contrary, AOD(500nm) of 0.62 was observed on March 29 at relatively moderate contamination of the ground level air (PM2.5 $=45 \mu \mathrm{g} \mathrm{m}^{-3}$ ). Also very low AOD occurred at the same level of PM2.5 (see Figure 8).

The large scattering of points relatively to the regression line can be explained by different smoke plumes observed by AirVisual devices and by the sun-photometer, particularly because different velocity of the air mass moving at the different altitudes. However, analysis of the back trajectories and satellite data on the fires location showed the same origin of the atmosphere contamination by the aerosols during period under study. It was the forest fires on the large area of the Ukraine and surrounding territories of Belarus and Russia.

It was for the first time when the event of the large atmosphere contamination was observed in Kyiv simultaneously by the sun-photometer and devices for PM2.5 measurements. Previously the comparison was made to reveal and quantify the influence of the aerosol particles concentration in the near-ground air in the Kyiv city on the columnar aerosol content measured by AOD without the fires influence [7]. Daily AOD(500nm) 
Level 1.5 and daily averaged PM2.5 and PM10 measured with the laser monitor SDL607 in different locations at different daytime during transects campaign were compared. The measurements of the AOD and PM performed during 32 days were selected for analysis between June and October 2017. The AERONET algorithm [44] determines AOD(500nm) for total particles in the atmosphere column, and separately for fine mode $(0.05-1.0 \mu \mathrm{m})$ and coarse mode $(1.0-15 \mu \mathrm{m})$ particles. PM2.5 concentrations were compared with fine mode $A O D(500 \mathrm{~nm})$ and PM10 values with total $\mathrm{AOD}(500 \mathrm{~nm})$. Linear regression equation for $\mathrm{AOD}(500 \mathrm{~nm})$ (see equation (1)) was used to quantify the AOD versus PM relations. Obtained parameters of the regression were: total AOD $(500 \mathrm{~nm})$ versus PM10: $a=$ $0.03 \pm 0.05 ; b=0.007 \pm 0.002$, the Pearson's correlation coefficient $r=0.52$, standard deviation of the points from regression line $\mathrm{SD}=0.08$. Fine mode $\mathrm{AOD}(500 \mathrm{~nm})$ versus $\mathrm{PM} 2.5 \mathrm{a}$ $=0.025 \pm 0.03 ; \mathrm{b}=0.006 \pm 0.002, \mathrm{R}=0.57, \mathrm{SD}=0.05$.

The biomass burning (BB) aerosol was recognized as a special aerosol type for remote sensing and study of aerosol significance in the atmosphere. Smoke particle properties are well understood qualitatively [47]. For example, approximately $80-90 \%$ of their volume is in the accumulation mode (particle diameters $<1 \mu \mathrm{m}$ ). Smoke particles are composed of $50-60 \%$ organic carbon and $5-10 \%$ black carbon. Specific size distribution parameters, SSA and RI were identified for the biomass burning aerosols originated from different types of burning vegetation and smoke age (e.g., [47,48]). Such agents as type of burning vegetation (trees, crown or stem of a tree, grass, peat etc.), meteorological conditions, time of the smoke transport to the observational site (aerosol age) specify the size, structure, chemical composition and optical properties of the smoke particles $[3,4,6,10,49-51]$, particularly absorption properties of the particles. To estimate the separate effect of each factor and the effect in combinations of factors, special studies and experiments were performed to determine optical properties of combustion particles generated from various fuels, see e.g. [52-54]. It is also know from large number of studies that properties and chemical composition of the biomass burning aerosol particles change significantly with age of smoke (see, e.g., new study [51]).

The properties of aerosol particles in smoke from vegetation burning are very various because depend on fuel type and moisture, combustion phase, wind conditions, and several other variables. Also, the physical, chemical, and optical properties of BB aerosols can change rapidly when they disperse in the atmosphere. Therefore, we can only estimate the columnar biomass burning aerosol particles properties observed at certain site for certain time.

Particle emissions from biomass burning are dominated by an accumulation mode, with a volume median diameter of $0.25-0.3 \mu \mathrm{m}$ range (count median diameter of 100-150 $\mathrm{nm}$ ) depending on age, fuel and combustion efficiency [47]. Dubovik et al. [48] obtained the fine mode particles volume $\mathrm{RMed}=0.13-0.16 \mu \mathrm{m}$ depending on burned vegetation at different region of the globe (Amazonian forest and Brazil cerrado, African savanna, US and Canada boreal forest), and coarse mode RMed $=3.4 \mu \mathrm{m}$ for boreal forest fires and approximately 3.8-3.9 $\mu \mathrm{m}$ for the others noted vegetation fires. The particle size distribution of fresh smoke is typically dominated by a lognormal accumulation mode particles with median diameter of $120 \mathrm{~nm}$ [52]. The aerosols particle properties can be determined more precisely for certain region from the sun-photometer observation.

During events of significant contamination of the atmosphere over Kyiv in March April 2020, time of smoke travel was estimated with the HYSPLIT model back trajectories. Location of the fires and smoke origin were determined for April 17 (Figure 4b) and age of aerosols was not more than approximately 10 hours. In order to reach Kyiv AERONET site on March 27 - 29 the air mass traveled more than 2 to 3 days over large area where fires took place (Figure 1a), and aerosol observed on those days was mixture of the particles of different age. However, following [55] we can consider the aerosol observed at Kyiv site as fresh during March and April events. Therefore, the particle size distribution is dominated by a lognormal accumulation mode, which is a fine mode in terms of the AERONET algorithm. The volume median radius of the fine mode particles 
vary from 0.10 to $0.23 \mu \mathrm{m}$ and generally corresponds to data of other studies, e.g. $[47,48,52,55]$. In addition, the lognormal particle size distributions for most of cases are predominant by fine mode except March 29, when the coarse mode dominates (Figures 6a). Standard deviation (STD) of volume median radius retrieved by Version 3 AERONET algorithm depend on the total particles AOD $(440 \mathrm{~nm})$ [34]. Special procedure for the STD estimation of the aerosol particles parameters created by AERONET team and named U27 (see the AERONET technical document "Description of Aerosol Inversion Uncertainty for Level 2 Products" [36]. The procedure takes into consideration the uncertainties in the sun-photometer radiometric calibration, $\mathrm{AOD}(440 \mathrm{~nm})$ measurements, solar spectral irradiance, and surface reflectance which results in 27 distinct combinations of the perturbed input parameters to the inversion procedure algorithm.

For all our cases the $\operatorname{AOD}(440 \mathrm{~nm})$ is in range $0.34-1.60$, and uncertainties of the fine mode particles RMed and STD can be estimated using data demonstrated by [34] for sites with dominant biomass burning and urban/industrial aerosols. The uncertainties of the fine mode particles RMed are 0.03 to $0.06 \mu \mathrm{m}$ and of the size distribution width for fine mode is 0.008 to $0.013 \mu \mathrm{m}$. Also it can be noted that the coarse mode particles RMed obtained from our observations during events in March and April is approximately 1.90 to $4.20 \mu \mathrm{m}$. This range is larger than obtained in [43]. It is evidence of complexity of coarse aerosol mixture in the considered case. It is necessary to note, the data of the cited authors are the summary during several years of observations, while our results were obtained from case study.

The optical properties of biomass burning (BB) aerosols were also studied by many authors for different type of burning vegetation in different region of globe, for example [48-50] and the others. The biomass-burning aerosol includes significant portion of organic matter, particularly black carbon, which is typically a dominant component of BB aerosol [49] making high absorbing capacity of the aerosols. SSA and RI of the biomass-burning aerosol depend on temperature of the combustion and burning substance such as trees, peat or grass as well as on phase of burning. In addition, the SSA and RI of particles depend on the meteorological conditions along the particles trajectory and on the time of their transport from fire location to the observational site. The results of spectral SSA of the BB aerosol from AERONET observation during 1993-2000, summarized over 2 to 5 years for different locations on the globe, were published in [48]. The SSA at standard AERONET wavelengths 440, 675, 870 and $1020 \mathrm{~nm}$ is different for different burning vegetation. The most absorbing aerosol originated from African savanna fires has the averaged SSA values equal to approximately $0.88,0.84,0.80$, and 0.78 at noted wavelengths respectively, while SSA from the USA and Canadian forest fires are $0.94,0.935,0.92$ and 0.91 . The later results of [50] that analyzed the AERONET observations of the biomass burning cases in different geographical zones of the world became expansion of the [48] data. The SSA data from that study differ a little from [48] results and demonstrate similar spectral features. Properties of boreal forest burning aerosol with contributions from peat fires (likely mostly dominated by smouldering combustion), are characterized by the weakest absorption with SSA close to spectrally neutral. Typical SSA at $500 \mathrm{~nm}$ ranges from $0.95-0.97$ (sites dominated by boreal forest or peat burning) to 0.88-0.9 (sites most influenced by grass, shrub, or crop burning). The strongest absorption is observed in southern African savanna with average SSA $(500 \mathrm{~nm})=$ 0.85 . SSA spectral dependence also is different for absorption properties of the particles. Particles with stronger absorption tend to have stronger spectral gradients in SSA, with more absorbing capacity at longer wavelengths [50]. Reviewing and comparing the optical properties of biomass burning particles estimated from in situ measurements, forward calculations, and inversions studies by Reid et al. [49] give best estimates for median values of smoke optical properties, emphasizing that each fire has its own character and can deviate significantly from the mean. Particularly, Reid et al. [49] emphasize also importance of smoke aging for particles properties and give the results of SSA in situ measurements of fresh and aged aerosols from different vegetation fires. The results 
showed that SSA of fresh smoke is lower than aged one, and particles from temperate and boreal forest fires are the least absorbing comparing to particles originated from savanna grass fires.

The forests in the north region of Ukraine with latitudes approximately $51-52^{\circ} \mathrm{N}$ are located on the border of the temperate and boreal zones, and in general, the properties of the smoke particles observed at Kyiv site during the fires in March - April 2020 agree with cited results for this type of burning vegetation. On base of data from GSFC AERONET site [39] we can estimate the uncertainties of spectral SSA for Kyiv AERONET site at events under study to be approximately not more than 0.025 at $440 \mathrm{~nm}, 0.030$ at $675 \mathrm{~nm}$, 0.035 at $870 \mathrm{~nm}$ and 0.045 at $1020 \mathrm{~nm}$. Values of the real $\mathrm{RI}(440 \mathrm{~nm})$ can be estimated by the same methodology as to be less than 0.02 for $\operatorname{AOD}(440 \mathrm{~nm})>0.4$, and for the imagery $\mathrm{RI}(440 \mathrm{~nm})$ the uncertainty given in [39] is less than 0.004 . Variability of the optical properties and chemical composition of the aerosol particles in the smoke plumes, which have passed over Kyiv (Figure 7), were caused by different burning material and phases of fires at different time. These features of the BB aerosols are typical for the region.

\section{Conclusions}

The first results of the recently created local network of AirVisual devices for surface air quality monitoring in Kyiv using PM2.5 concentration measurements are presented in the paper. The network consists of five sites located in different areas of the city. Sites determine the Air Quality Index (AQI), the concentration of suspended particles PM2.5, air temperature, the concentration of carbon dioxide $\mathrm{CO} 2$.

In the paper, we examine in detail the results of measurements of AirVisual stations, APDA-371 HORIBA Popudrenka station and AERONET Kyiv station, air pollution by aerosol particles in the city of Kyiv in the March-April 2020 period during forest fires on large areas in the northern region of the Kyiv city.

The properties of aerosol particles during pollution according to the measurements of AERONET Kyiv station are also considered. These data allowed us to estimate variations in the size of aerosol particles and to make assumptions about their nature according to the Angstrom AE parameter and its dependence on AOD at different wavelengths.

In the nearest future, we plan to expand the network of AirVisual stations to obtain detailed information in other areas of Kyiv and to inform Kyiv residents about the state of air pollution. It also is planned to assess the risks of aerosol pollution on the health of Kyiv residents based on measurements in the AirVisual network and other existing tools. The discussed case of enormous PM2.5 aerosol contamination in Kyiv city emerges the needs to accept strong measures for forest fire control and prevention in Kyiv region especially at north-west area where radioactive contamination from Chornobyl disaster is still significant and impacted on ecosystem [56].

Author Contributions: Conceptualization, G.M. and V.D.; methodology, V.D., O.T. and G.M.; software, V.D., V.K., Y.Y. and M.S.; validation, V.D., O.T., V.S. and G.M.; investigation, I.S., M.S., A.S., V.C., T.M., V.M., V.P., W.H. and A.H.; writing-original draft preparation, G.M., V.D. and Y.Y.; writing - review and editing, G.M., V.D., N.M. and Y.Y.; visualization, A.P., V.K., Y.Y., V.D. and O.I.; supervision, G.M. and V.S.; project administration, G.M. and V.S. Each author contributed to the interpretation and discussion of the results and edited the manuscript. All authors have read and agreed to the published version of the manuscript.

Funding: This research received no external funding.

Acknowledgments: This work was partly supported by College of Physics International Center of Future Science, Jilin University, China; by the National Antarctic Scientific Center and Ministry of Education and Science of Ukraine, Kyiv, through the projects 20BF051-02; by the Belarusian Republican Foundation for Fundamental Research through the project F20UKA-017 and National Academy of Sciences of Ukraine through the project 01-01-20/21. We acknowledge the use of im- 
agery modified by authors from the NASA Worldview application (https://worldview.earthdata.nasa.gov), part of the NASA Earth Observing System Data and Information System (EOSDIS). This work also was partly supported by the European Union's Horizon 2020 research and innovation program under ACTRIS-2 grant agreement No 654109. We thank Brent Holben (NASA/GSFC) for managing the AERONET program and its sites. The high quality of AERONET/PHOTONS data was provided by CIMEL sun-photometer calibration performed at the AERONET-EUROPE calibration center. The authors would like also to acknowledge the European Commission 'Horizon 2020 Program' that funded the ERA-PLANET/SMURBS project.

Conflicts of Interest: The authors declare no conflict of interest.

\section{References}

1. Konovalov, I.B.; Beekmann, M.; Kuznetsova, I.N.; Yurova, A.; Zvyagintsev, A.M. Atmospheric impacts of the 2010 Russian wildfires: integrating modelling and measurements of an extreme air pollution episode in the Moscow region. Atmos. Chem. Phys. 2011, 11, P. 10031-10056.

2. Chubarova, N.; Nezval', Ye.; Sviridenkov, I.; Smirnov, A.; Slutsker, I. Smoke aerosol and its radiative effects during extreme fire event over Central Russia in summer 2010. Atmos. Meas. Tech. 2012, 5, 557-568.

3. Portin, H.; Mielonen, T.; Leskinen, A.; Arola, A.; Pärjälä, E.; Romakkaniemi, S.; Laaksonen, A.; Lehtinen, K.E.J.; Komppula, M. Biomass burning aerosols observed in Eastern Finland during the Russian wildfires in summer 2010 - Part 1: In-situ aerosol characterization. Atmospheric Environment 2012, 47, 269 - 278. https://doi.org/10.1016/j.atmosenv.2011.10.067.

4. Mielonen, T.; Portin, H.; Komppula, M.; Leskinen, A.; Tamminen, J.; Ialongoc, I.; Hakkarainen, J.; Lehtinen, K.E.J.; Arola, A. Biomass burning aerosols observed in Eastern Finland during the Russian wildfires in summer 2010 e Part 2: Remote sensing. Atmospheric Environment 2012, 47, 279 - 287. doi:10.1016/j.atmosenv.2011.07.016.

5. Galytska, E.; Danylevsky, V.; Hommel, R.; Burrows, J.P. Increased aerosols content in the atmosphere over Ukraine during summer 2010. Atmos. Meas. Tech. 2018, 11, 2101-2118, doi:10.5194/amt-11-2101-2018.

6. Markowicz, K.M.; Chilinski, M.T.; Lisok, J.; Zawadzka, O.; Stachlewska, I.S.; Janicka, L.; Rozwadowska, A.; Makuch, P.; Pakszys, P.; Zielinski, T.; et al. Study of aerosol optical properties during long-range transport of biomass burning from Canada to Central Europe in July 2013. Journal of Aerosol Science 2016, 101, P.156-173.

7. Shelestov, A.; Kolotii, A.; Borisova, T.; Turos, O.; Milinevsky, G.; Gomilko, I.; Bulanay, T.; Fedorov, O.; Shumilo, L.; Pidgorodetska, L.; et al. Essential variables for air quality estimation. International Journal of Digital Earth 2020, 13:2, 278 298, https://doi.org/10.1080/17538947.2019.1620881.

8. Haënninen, O. O.; Salonen, R. O.; Koistinen, K.; Lanki, T.; Barregard, L.; Jantunen, M. Population exposure to fine particles and estimated excess mortality in Finland from an East European wildfire episode. Journal of Exposure Science and Environmental Epidemiology 2009, 19, $414-422$.

9. Lanzinger, S.; Schneider, A.; Breitner, S.; Stafoggia, M.; Erzenc, I.; Dostal, M.; Pastorkova, A.; Bastian, S.; Cyrys, J.; Zscheppang, A.; et al. Associations between ultrafine and fine particles and mortality in five central European cities Results from the UFIREG study. Environment International 2016, 88, 44-52. http://dx.doi.org/10.1016/j.envint.2015.12.006.

10. Putaud, J.-P.; Van Dingenen, R.; Alastuey, A.; Bauer, H.; Birmili, W.; Cyrys, J.; Flentje, H.; Fuzzi, S.; Gehrig, R.; Hansson, H.C.; et al. A European aerosol phenomenology - 3: Physical and chemical characteristics of particulate matter from 60 rural, urban, and kerbside sites across Europe. Atmospheric Environment 2010, 44, 1308 - 1320. doi:10.1016/j.atmosenv.2009.12.011.

11. Amaral, S.S.; de Carvalho Jr., J.A.; Martins Costa, M.A.; Pinheiro, C. An Overview of Particulate Matter Measurement Instruments. Atmosphere 2015, 6, 1327-1345, doi:10.3390/atmos6091327.

12. Huang, K.; Xiao, Q.; Meng, X.; Geng, G.; Wang, Y.; Lyapustin, A.; Gu, D.; Liu, Y. Predicting monthly high-resolution PM2.5 concentrations with random forest model in the North China Plain. Environmental Pollution 2018, 242,675 - 683. https://doi.org/10.1016/j.envpol.2018.07.016.

13. Samek, L.; Turek-Fijak, A.; Skiba, A.; Furman, P.; Styszko, K.; Furman, L.; Stegowski, Z. Complex Characterization of Fine Fraction and Source Contribution to PM2.5 Mass at an Urban Area in Central Europe. Atmosphere 2020, 11, 1085, doi:10.3390/atmos11101085.

14. Abera, A.; Mattisson, K.; Eriksson, A.; Ahlberg, E.; Sahilu, G.; Mengistie, B.; Bayih, A.G.; Aseffaa, A.; Malmqvist, E.; Isaxon C. Air Pollution Measurements and Land-Use Regression in Urban Sub-Saharan Africa Using Low-Cost Sensors-Possibilities and Pitfalls. Atmosphere 2020, 11, 1357; doi:10.3390/atmos11121357.

15. Fattoruso, G.; Nocerino, M.; Toscano, D.; Pariota, L.; Sorrentino, G.; Manna, V.; De Vito, S.; Cartenì, A.; Fabbricino, M; Di Francia, G. Site Suitability Analysis for Low Cost Sensor Networks for Urban Spatially Dense Air Pollution Monitoring. Atmosphere 2020, 11, 1215, doi:10.3390/atmos11111215).

16. Schaap, M.; Apituley, A.; Timmermans, R.M.A.; Koelemeijer, R.B.A.; de Leeuw, G. Exploring the relation between aerosol optical depth and PM2.5 at Cabauw, the Netherlands. Atmos. Chem. Phys. 2009, 9, 909-925. 
17. Van Donkelaar, A.; Martin, R.V.; Levy, R.C.; da Silva, A.M.; Krzyzanowski, M.; Chubarova, N.E.; Semutnikova E.; Cohen A.J. Satellite-based estimates of ground-level fine particulate matter during extreme events: A case study of the Moscow fires in 2010. Atmospheric Environment 2011, 45, 6225 - 6232, doi:10.1016/j.atmosenv.2011.07.068.

18. Bovchaliuk, A. The spatial variability of PM2:5 over Europe using satellite POLDER-3/PARASOL data. Advances in Astronomy and Space Physics 2013, 3, 102-108.

19. Gao, C.; Zhang, X.; Wang, W.; Xiu, A.; Tong, D.Q.; Chen, W. Spatiotemporal Distribution of Satellite-Retrieved Ground-Level PM2.5 and Near Real-Time Daily Retrieval Algorithm Development in Sichuan Basin, China. Atmosphere 2018, 9, 78; doi:10.3390/atmos9020078.

20. Chu, Y.; Liu, Y.; Li, X.; Liu, Z.; Lu, H.; Lu, Y.; Mao, Z.; Chen, X.; Li, N.; Ren, M.; et al. A Review on Predicting Ground PM2.5 Concentration Using Satellite Aerosol Optical Depth. Atmosphere 2016, 7, 129, doi:10.3390/atmos7100129.

21. Lennartson, E.M.; Wang, J.; Gu, J.; Garcia, L.C.; Ge, C.; Gao, M.; Choi, M.; Saide, P.E.; Carmichael, G.R.; Kim, J.; Janz, S.J. Diurnal variation of aerosol optical depth and PM2:5 in South Korea: a synthesis from AERONET, satellite (GOCI), KORUS-AQ observation, and the WRF-Chem model. Atmos. Chem. Phys. 2018, 18, 15125-15144. https://doi.org/10.5194/acp-18-15125-2018.

22. Yang, S.H.; Jeong, J.I.; Park R.J.; Kim, M.J. Impact of Meteorological Changes on Particulate Matter and Aerosol Optical Depth in Seoul during the Months of June over Recent Decades. Atmosphere 2020, 11, 1282.1 - 19, doi:10.3390/atmos11121282.

23. Zhao, F.; Liu, Y.; Shu, L.; Zhang, Q. Wildfire Smoke Transport and Air Quality Impacts in Different Regions of China. Atmosphere 2020, 11, 941.1 - 24, doi:10.3390/atmos11090941.

24. Evangeliou, N.Y.; Balkanski, Y.; Cozic, A.; Hao, W.M.; Mouillot, F.; Thonicke, K.; Paugam, R.; Zibtsev, S.; Mousseau, T.A.; Wang, R.; et al. Fire evolution in the radioactive forests of Ukraine and Belarus: future risks for the population and the environment. Ecological Monographs 2015, 85(1), 49-72, https://doi.org/10.1890/14-1227.1.

25. Milinevsky, G.; Danylevsky, V.; Bovchaliuk, V.; Bovchaliuk, A.; Goloub, Ph.; Dubovik, O.; Kabashnikov, V.; Chaikovsky, A.; Miatselskaya, N.; Mishchenko M.; Sosonkin, M. Aerosol seasonal variations over urban-industrial regions in Ukraine according to AERONET and POLDER measurements. Atmos. Meas. Tech. 2014, 7, 1459-1474.

26. Bovchaliuk, A.; Milinevsky, G.; Danylevsky, V.; Goloub, P.; Dubovik, O.; Holdak, A.; Ducos F.; Sosonkin, M. Variability of aerosol properties over Eastern Europe observed from ground and satellites in the period from 2003 to 2011 . Atmos. Chem. Phys. 2013, 13, 6587- 6602, doi:10.5194/acp-13-6587-2013.

27. Kabashnikov, V.; Milinevsky, G.; Chaikovsky, A.; Miatselskaya, N.; Danylevsky, V.; Aculinin, A.; Kalinskaya, D.; Korchemkina, E.; Bovchaliuk, A.; Pietruczuk, A. et al. Localization of aerosol sources in East-European region by back-trajectory statistics. International Journal of Remote Sensing 2014, 35, 6993-7006, doi:10.1080/01431161.2014.960621.

28. Miatselskaya, N.; Kabashnikov, V.; Milinevsky, G.; Chaikovsky, A.; Danylevsky, V.; Bovchaliuk, V. Atmospheric aerosol distribution in the Belarus-Ukraine region by the GEOS-Chem model and AERONET measurements. International Journal of Remote Sensing 2016, 37(14), 3181-3195, doi.org/10.1080/01431161.2016.1194541.

29. Miatselskaya, N. S.; Kabashnikov, V.P.; Norka, H.V.; Chaikovsky, A.P.; Bril, A.I.; Milinevsky, G.P. ; Danylevsky, V. O. Atmosphere aerosol modeling by GEOS-Chem for the AEROSOL-UA space project validation. Space Science and Technology 2017, 23, 3-10. doi.org/10.15407/knit2017.03.003.

30. Holben, B. N.; Eck, T.F.; Slutsker, I.; Tanré, D.; Buis, J.P.; Setzer, A.; Vermote, E.; Reagan, J.A.; Kaufman, Y.J.; Nakajima, T.; et al. AERONET - A Federated Instrument Network and Data Archive for Aerosol Characterization. Remote Sens. Environ. 1998, 66, 1-16. https://doi.org/10.1016/S0034-4257(98)00031-5

31. Holben, B.N.; Kim, J.; Sano, I.; Mukai, S.; Eck, T.F.; Giles, D.M.; Schafer, J.S.; Sinyuk, A.; Slutsker, I.; Smirnov, A. et al. An overview of mesoscale aerosol processes, comparisons, and validation studies from DRAGON networks. Atmos. Chem. Phys. 2018, 18, 655-671. doi:10.5194/acp-18-655-2018.

32. ZoomEarth: NOAA/NESDIS/STAR, EUMETSAT, JMA/NOAA/CIRA global weather satellite images. Available online: https://zoom.earth/ (accessed on 15 July 2021).

33. FIRMS: Fire Information for Resource Management System of NASA's Earth Observing System Data and Information System (EOSDIS). Available online: https://earthdata.nasa.gov/firms (accessed on 15 December 2021).

34. IQAir AirVisual Series. Available online: https://www.iqair.com/air-quality-monitors/airvisual-pro (accessed on 15 December 2021).

35. IQAir Air quality in the world. Available online: https://airvisual.com/world (accessed on 15 December 2021).

36. AERONET Data Synergy Tool. Available online: https://aeronet.gsfc.nasa.gov/cgi-bin/bamgomas_interactive (accessed on 22 December 2021).

37. Dubovik, O.; King, M.D. A flexible inversion algorithm for retrieval of aerosol optical properties from Sun and sky radiance measurements. J. Geophys. Res. 2000, 105, 20 673-20 696.

38. Giles, D. M.; Sinyuk, A.; Sorokin, M.G.; Schafer, J.S.; Smirnov, A.; Slutsker, I.; Eck, T.F.; Holben, B.N.; Lewis, J.R.; Campbell, J.R.; et al. Advancements in the Aerosol Robotic Network (AERONET) Version 3 database - automated near-real-time quality control algorithm with improved cloud screening for Sun photometer aerosol optical depth (AOD) measurements. Atmos. Meas. Tech. 2019, 12, 169-209, doi: https://doi.org/10.5194/amt-12-169-2019. 
39. Sinyuk, A.; Holben, B.N.; Eck, T.F.; Giles, D.M.; Slutsker, I.; Korkin, S.; Schafer, J.S.; Smirnov, A.; Sorokin, M.; Lyapustin. A. The AERONET Version 3 aerosol retrieval algorithm, associated uncertainties and comparisons to Version 2. Atmos. Meas. Tech. 2020, 13, 3375-3411, https://doi.org/10.5194/amt-13-3375-2020.

40. Milinevsky, G.; Danylevsky, V. Atmospheric Aerosol Over Ukraine Region: Current Status of Knowledge and Research Efforts. Frontiers in Environmental Science 2018, 6, 59. DOI=10.3389/fenvs.2018.00059

41. Draxler, R.R.; Hess, G.D. An overview of the HYSPLITp4 modeling system for trajectories, dispersion, and deposition. Aust. Meteor. Mag. 1997, 47, 295 - 308.

42. Stein, A.F.; Draxler, R.R.; Rolph, G.D.; Stunder, B.J.B.; Cohen, M.D.; Ngan, F. NOAA's HYSPLIT atmospheric transport and dispersion modeling system. Bull. Amer. Meteor. Soc. 2015, 96, 2059-2077, http://dx.doi.org/10.1175/BAMS-D-14-00110.1

43. Stohl, A. Computation, accuracy and applications of trajectories - a review and bibliography. Atmospheric Environment 1998, 32, $947-966$.

44. O'Neill, N.T.; Eck, T.F.; Smirnov, A.; Holben, B.N.; Thulasiraman, S. Spectral discrimination of coarse and fine mode optical depth. J. Geophys. Res. 2003, 108(D17), 4559-4573. 10.1029/2002JD002975/

45. Bovchaliuk, V.P.; Milinevsky, G.P.; Danylevsky, V.O.; Golub, Ph.; Sosonkin, M.G.; Yukhimchuk, Yu.; Podvin, T. Properties of aerosol in the atmosphere over Kiev by lidar and photometric observations. Space Science and Technology 2017, 23, 3747, http://knit.mao.kiev.ua/en/archive/2017/6/05.

46. Boucher, O. Atmospheric Aerosols. Properties and Climate Impacts. Springer, Netherlands, 2015 , 311 p., DOI 10.1007/978-94-017-9649-1.

47. Reid, J.S.; Koppmann, R.; Eck, T.F.; Eleuterio. D.P. A review of biomass burning emissions part II: intensive physical properties of biomass burning particles. Atmos. Chem. Phys. 2005a, 5, 799-825, https://doi.org/10.5194/acp-5-799-2005

48. Dubovik, O.; Holben, B.; Eck, Th.F.; Smirnov, A.; Kaufman, Y.J.; King, M.D.; Tanré, D.; Slutsker, I. Variability of absorption and optical properties of key aerosol types observed in worldwide locations. Journal of the Atmospheric Sciences 2002, 59, 590-608, doi:10.1175/1520-0469(2002)059<0590:VOAAOP>2.0.CO;2

49. Reid, J.S.; Eck, T.F.; Christopher, S.A.; Koppmann, R.; Dubovik, O.; Eleuterio, D.P.; Holben, B.N.; Reid, E.A.; Zhang, J. A review of biomass burning emissions part III: intensive optical properties of biomass burning particles. Atmos. Chem. Phys. 2005b, 5, 827-849, www.atmos-chem-phys.org/acp/5/827/.

50. Sayer, A.M.; Hsu, N.C.; Eck, T.F.; Smirnov, A.; Holben, B.N. AERONET-based models of smoke-dominated aerosol near source regions and transported over oceans, and implications for satellite retrievals of aerosol optical depth. Atmos. Chem. Phys. 2014, 14, 11493 - 11523, doi:10.5194/acp-14-11493-2014.

51. Konovalov, I.B.; Golovushkin, N.A.; Beekmann, M.; Andreae, M.O. Insights into the aging of biomass burning aerosol from satellite observations and 3D atmospheric modeling: evolution of the aerosol optical properties in Siberian wildfire plumes. Atmos. Chem. Phys. 2021, 21, 357-392. https://doi.org/10.5194/acp-21-357-2021/.

52. Janhäll, S.; Andreae, M.O.; Pöschl, U. Biomass burning aerosol emissions from vegetation fires: particle number and mass emission factors and size distributions. Atmos. Chem. Phys. 2010, 10, 1427-1439, www.atmos-chem-phys.net/10/1427/2010/.

53. Levin, E.J.T.; McMeeking, G.R.; Carrico, C.M.; Mack, L.E.; Kreidenweis, S.M.; Wold, C.E.; Moosmüller, H.; Arnott, W.P.; Hao, M. W.; Collett Jr., J.L.; Malm, W.C. Biomass burning smoke aerosol properties measured during Fire Laboratory at Missoula Experiments (FLAME). J. Geophys. Res. 2010, 115, D18210, doi:10.1029/2009JD013601.

54. Kim, J.; Bauer, H.; Dobovičnik, T.; Hitzenberger, R.; Lottin, D.; Ferry, D.; Petzold, A. Assessing Optical Properties and Refractive Index of Combustion Aerosol Particles Through Combined Experimental and Modeling Studies. Aerosol Science and Technology 2015, 49,340 - 350, doi: 10.1080/02786826.2015.1020996.

55. Alados-Arboledas, L.; Müller, D.; Guerrero-Rascado, J.L.; Navas-Guzmán, F.; Pérez-Ramírez, D.; Olmo, F.J. Optical and microphysical properties of fresh biomass burning aerosol retrieved by Raman lidar, and starand sun-photometry. Geophys. Res. Lett. 2011, 38, L01807, doi:10.1029/2010GL045999.

56. Mousseau, T.A. The Biology of Chernobyl. Annual Review of Ecology, Evolution, and Systematics 2021, 52(1), 87-109. doi:10.1146/annurev-ecolsys-110218-024827. 